\title{
In Vitro Safety Evaluation of Caffeic Acid
}

\author{
By Caroline Magnani* \\ Bruna Galdorfini Chiari ${ }^{\dagger}$ \\ Vera Lucia Borges Isaac \\ Marcos Antonio Correa ${ }^{+}$ \\ Herida Regina Nunes Salgado
}

Phenolic compounds are abundant in the Brazilian plant kingdom and they are part of a large and complex group of organic substances. Cinnamic acids are part of this group of organic compounds, and caffeic acid is one of its representatives. Besides exhibiting a powerful antioxidant activity, increasing the collagen production and preventing the premature aging, caffeic acid has demonstrated antimicrobial activity and may be promising in the treatment of dermal diseases. One of the applications of caffeic acid is in emulsions, which are known to be widely used by consumers for pleasant and refreshing sensory, although few studies have reported the efficacy and safety of these products on the skin. The relevance of this study is based on evidence and to clarify the cytotoxic potential of this substance through preliminary studies in vitro. The cytotoxicity evaluation was carried out using the MTT method (3(4,5-dimethyl-2-thiazolyl)-2,5-diphenyl-2H-tetrazolium bromide), a colorimetric assay which determines the amount of insoluble violet crystals formed by the reduction of MTT in the mitochondria of living cells. A dose versus response curve was constructed, and it was possible to use the equation to determine the IC50 of caffeic acid or the product concentration needed to cause 50\% lethality of the cells. The results are promising since caffeic acid concentration that promoted $50 \%$ toxicity in HepG2 cells $(I C 50=781.8 \mu \mathrm{g} / \mathrm{mL})$ is approximately 330 to 400 times greater than the concentration required to inhibit $50 \%$ of DPPH $(I C 50 \mathrm{DPPH}=2.39 \mu \mathrm{g} / \mathrm{mL})$ and ABTS (IC50 ABTS $=1.96 \mu \mathrm{g} / \mathrm{mL})$ radicals scavenging activity, respectively. The maximum concentration of caffeic acid tested (1140 mg $/ \mathrm{mL}$ ) did not reach 50\% of cell death in HaCat cells. Thus, it was concluded that the caffeic acid does not cause toxicity in HepG2 and HaCat cells in the concentrations required to promote

\footnotetext{
*PhD Student, São Paulo State University, Brazil.

${ }^{\dagger}$ PhD Student, São Paulo State University, Brazil.

*Professor, São Paulo State University, Brazil.

${ }^{+}$Professor, São Paulo State University, Brazil.

'Professor, São Paulo State University, Brazil.
} 
antioxidant activity in vitro, and it can be applied in topical products.

\section{Introduction}

Phenolic compounds are abundant in the Brazilian plant kingdom and they are part of a large and complex group of organic substances. Cinnamic acid derivatives are part of this group of organic compounds, also called phenylpropanoids, which contains nine carbons in its structures (Figure 1). Caffeic acid (3,4-dihydroxycinnamic) is a representative of this group (Soares, 2002).

Figure 1. Chemical Structure of the Main Cinnamic Acids. Cinnamic Acid $R 1=R 2=R 3=R 4=H, o$-coumaric acid $: R 2=O H, p$-coumaric acid: $R 3=O H ;$ Caffeic Acid: $R 2=R 3=O H ;$ Ferulic Acid $: R 2=O \mathrm{CH}_{3}$ and $\mathrm{R} 3=\mathrm{OH}$

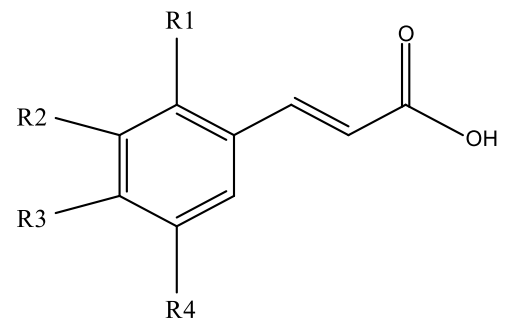

The phenolic antioxidants act as free radical scavengers and sometimes as metal chelators. They act both in the initiation step as well as in the propagation of the oxidative process. These substances are relatively stable owing to the resonance of the aromatic ring shown by them. The phenolic acids are characterized by the presence of a benzene ring, a carboxylic acid moiety and one or more hydroxyl or methoxy moieties in the molecule, which confer antioxidant properties to it (Aklillu et al.; 2014; Djordjevic et al. 2010; Dossiê de Antioxidantes, 2014). The phenylpropanoids act as antioxidants by eliminating oxygen free radicals (Chen et al., 1997; Meyer et al., 1998) and chelating pro-oxidant metal ions, especially iron (Paiva-Martins et al., 2002; Hynes et al., 2004).

Besides exhibiting a powerful antioxidant activity, increasing collagen production and preventing premature aging, caffeic acid has demonstrated antimicrobial activity and may be promising in the treatment of dermal diseases. One of the applications of caffeic acid is in emulsions, which are known to be widely used by consumers for pleasant and refreshing sensory, although few studies have reported the efficacy and safety of these products on the skin (Magnani et al., 2014).

The cosmetic industry and researchers have sought to use in vitro experiments, replacing animal models for the study of the efficacy and safety of new products in recent times. Additionally, the policy of the European Community has determined that cosmetic products produced and marketed in 
member countries should not use animals for conducting toxicological tests (Augustin et al., 1996).

As an alternative to animal testing, testing on cell cultures have been proposed in order to predict the toxic potential of chemicals and formulations (Livny et al., 2003; Viravaidya et al., 2004; Rabachini, 2007). Thus, the experiments in cell cultures enable the study of cellular behavior in a controlled microenvironment using non-tumor human epithelial cells (Bedoni et al., 2007; Heise et al., 2006). Culture of primary cells such as keratinocytes, skin explants, organs, or organotypic cultures of cells have been used in preclinical testing of natural products (Botham et al., 1998; Medina, 2000; Abu-Yousif et al., 2008).

As commensurate with the ongoing trend of replacing the in vivo tests of cosmetics, this study used in vitro techniques to assess the safety and efficacy of the product developed.

The aim of this study was to provide evidence and to clarify the cytotoxic potential of this substance through preliminary studies in vitro.

\section{Experimental Methods}

The cytotoxicity evaluation was carried out using the MTT method (3(4,5-dimethyl-2-thiazolyl)-2,5-diphenyl-2H-tetrazolium bromide), a colorimetric assay which determines the amount of insoluble violet crystal formed by the reduction of MTT in the mitochondria of living cells.

Two human cell lines were assessed: human hepatoma cells which are capable of metabolizing xenobiotics (HepG2) and metabolically incompetent keratinocytes (HaCat), grown in MEM (Minimum Essential Media) culture media with $10 \%$ of fetal bovine serum and antibiotics (penicillin $100 \mathrm{U} / \mathrm{ml}$, streptomycin $0.1 \mathrm{mg} / \mathrm{ml}$ ).

The cultures were maintained in an incubator at $37^{\circ} \mathrm{C}$ in an atmosphere of $5 \% \mathrm{CO}_{2}$ for, approximately, four weeks. The cells with confluence of 80 to 90\% were trypsinized, adding MEM with fetal bovine serum to neutralize the trypsin, centrifuged at $1200 \mathrm{rpm}$ for 3 minutes and, then, seeded in 96 well plates. Cell density required for cytotoxicity assays was $1 \times 10^{6}$ cells $/ \mathrm{ml}$.

The plates were incubated for 24 hours for effective adhesion of cells to the wells. For positive control, was added $1 \mathrm{ml}$ of $10 \%$ DMSO to the cells. The negative control was prepared using MEM. Finally, various concentrations of caffeic acid (solubilized in MEM with $0.5 \%$ DMSO) were added to the wells. To determine the effect of DMSO used to solubilize the CA in the cells, a control with DMSO was used for each treatment concentration (Figure 2).

The plates were then incubated for 24 hours. 
Figure 2. Scheme of Treatment of Cells in the 96-well Plate

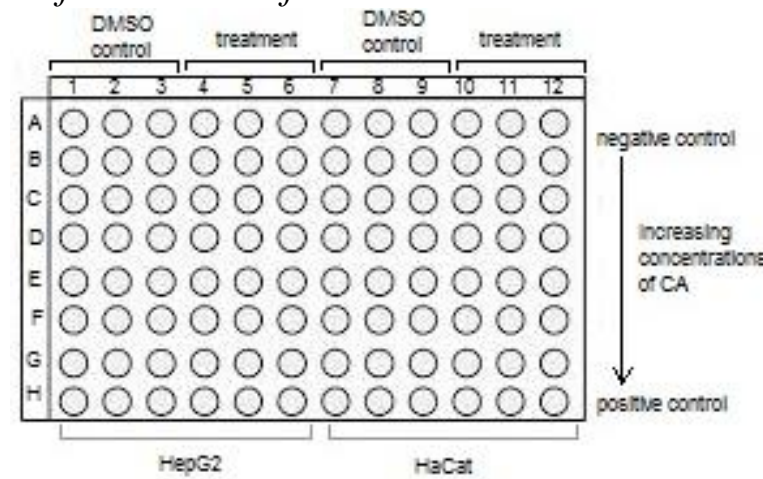

After this time, the treatment was removed, the plates were gently washed with Phosphate Buffer Saline (PBS) (Bruggisser et al., 2002), and $100 \mathrm{~mL}$ of MTT (1 mg / ml PBS) was added to each well. The presence of purple formazan crystals was observed after 3 to 5 hours of incubation at $37^{\circ} \mathrm{C}$ and protected from UV light. The method can be seen in the scheme of Figure 3.

Figure 3. Scheme of the Procedure used to Assess the Cytotoxicity of Caffeic Acid (CA) (Adapted from Chiari et al., 2012)

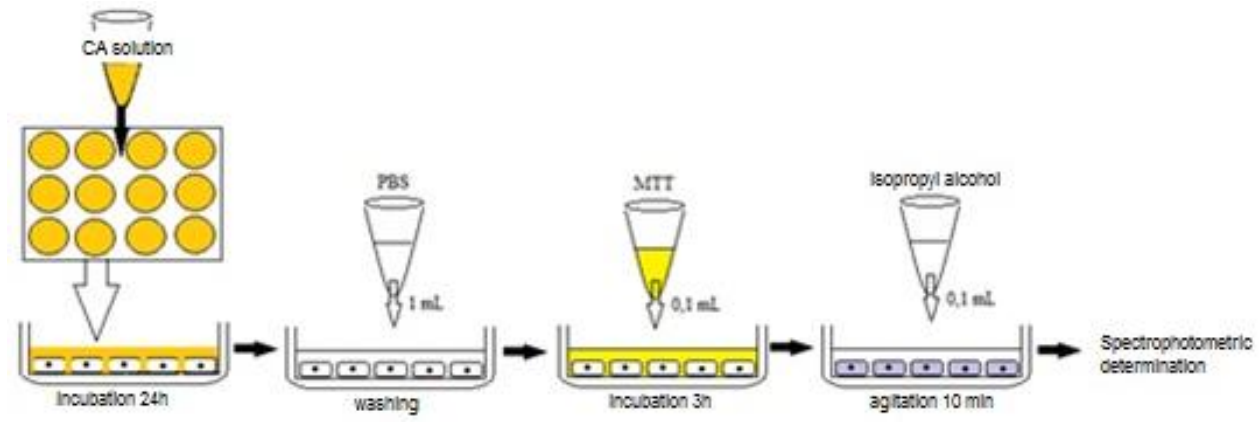

To solubilize the formazan crystals, $100 \mu \mathrm{L}$ of isopropyl alcohol were added to each well. Then, the spectrophotometric determination of absorbance was performed at a wavelength of $595 \mathrm{~nm}$ in a plate reader.

The percentage of dead cells was calculated in relation to the negative control, representing the cytotoxicity of each treatment, as proposed by Zhang et al. (2004), and the percentage of living cells was also subsequently determined. A dose versus response curve was constructed, where it was possible to use the equation to determine the $\mathrm{IC}_{50}$ of caffeic acid or the concentration of it needed to cause $50 \%$ lethality of the cells.

Cytotoxicity assays were performed on at least 3 independent experiments.

\section{Results and Discussion}

The cytotoxicity of caffeic acid was carried out using two cell lines, HepG2 and HaCat cells. HepG2 cells were chosen since they act as a parameter of the primary route of metabolism in the human body, thus making it possible 
to evaluate the toxicity of the product through its metabolite formed in these cells.

Since the focus of this study is the cosmetic area, HaCaT keratinocytes were selected as an analogue of the epidermis, thus being possible to verify the toxicity to the skin when the product is applied on it.

According to Bruggisser et al. (2002), an interaction between the MTT reagent and caffeic acid may occur, possibly due to the oxidizing action of caffeic acid that promotes the reduction of the MTT salt to form formazan crystals in the same manner as occurs in living cells, leading to a false positive result. To avoid this problem, the 96-well plates were washed gently with PBS to remove the caffeic acid and a solution of MTT was then added (Figure 4).

Figure 4. Culture of HepG2 Cells (left) and HaCaT Cells (right) after the Addition of MTT Solution

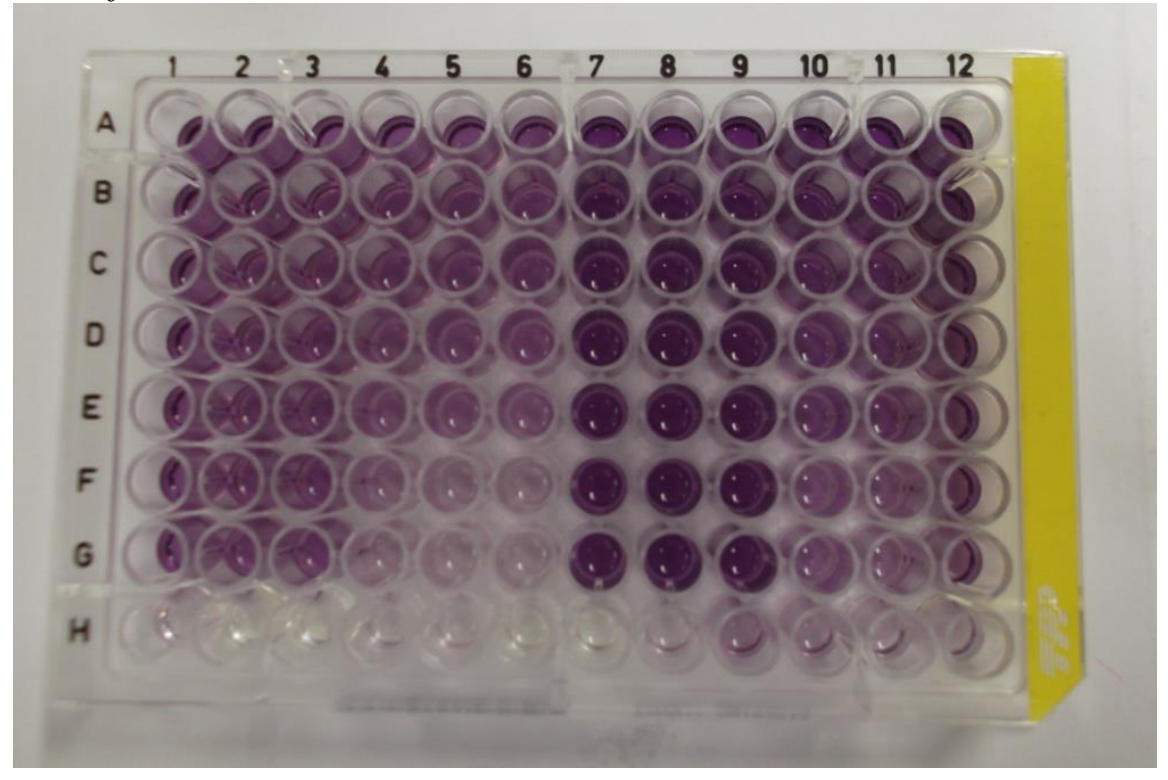

Figure 5 shows the results obtained for HepG2. A dose versus response curve was constructed where it was possible to use the equation generated by linear regression to determine the $\mathrm{IC}_{50}$ of caffeic acid, i.e. the product concentration needed to cause $50 \%$ lethality of the cells. 
Figure 5. Dose versus Response Curve of HepG2 Cells treated with various Concentrations of Caffeic Acid

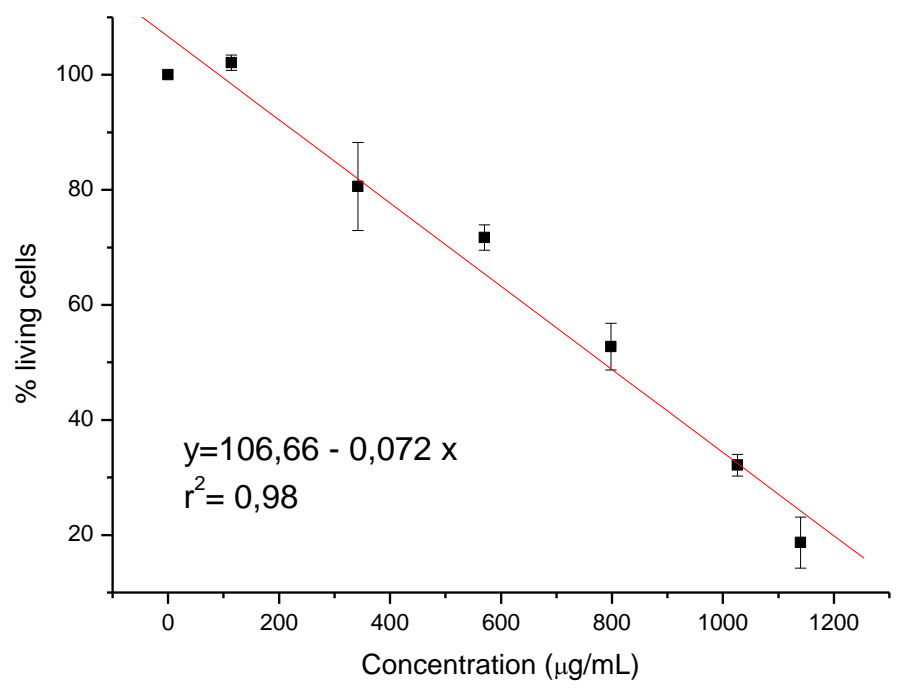

The same process was conducted for HaCat cells and results are seen in Figure 6 below.

Figure 6. Dose versus Response Curve of HaCat Cells treated with various Concentrations of Caffeic Acid

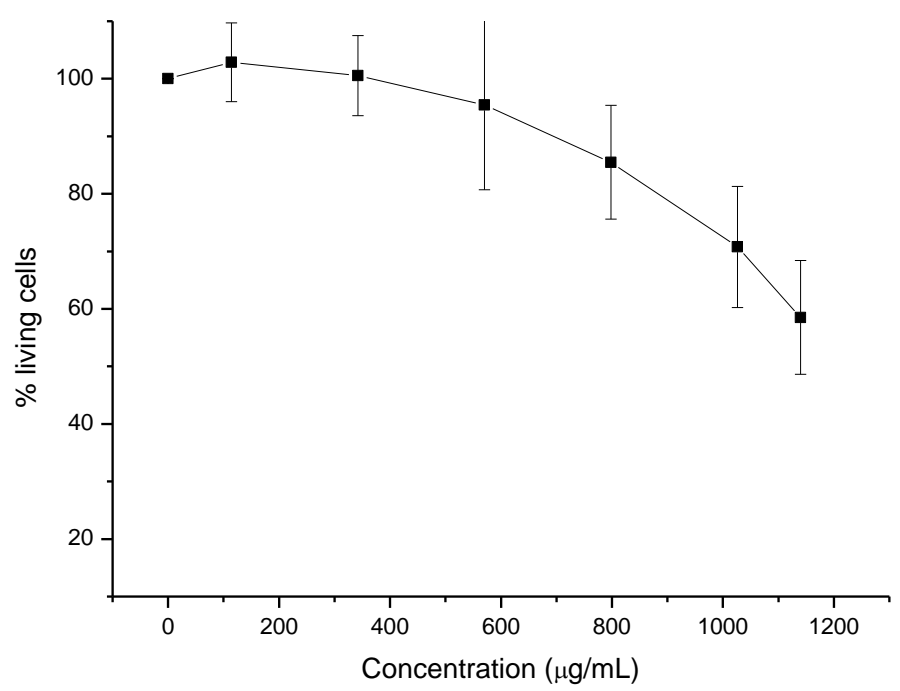

The results obtained are found to be promising since the caffeic acid concentration that was toxic for $50 \%$ of HepG2 cells $\left(\mathrm{IC}_{50}=781.8 \mu \mathrm{g} / \mathrm{mL}\right)$ is approximately 330 to 400 times greater than the concentration required to inhibit 50\% DPPH $\left(\mathrm{IC}_{50} \mathrm{DPPH}=2.39 \mu \mathrm{g} / \mathrm{mL}\right)$ and ABTS $\left(\mathrm{IC}_{50}\right.$ ABTS $=1.96$ $\mu \mathrm{g} / \mathrm{mL}$ ) free radicals scavengers, respectively. The maximum concentration of 
caffeic acid tested $(1140 \mu \mathrm{g} / \mathrm{mL})$ did not reach $50 \%$ of cell death in HaCat cells.

\section{Conclusion}

For the cytotoxicity assay, it was concluded that the caffeic acid does not promotes toxicity in HepG2 and HaCat cells in the concentration needed to exhibit antioxidant activity in vitro and, thus, it can be applied in topical products.

\section{Acknowledgments}

Our thank to FAPESP, CNPq and PADC-FCF-UNESP for the financial support.

\section{References}

Abu-Yousif, A. O., Smith, K.A., Getsios, S., Green, K.J., Van Dross, R.T., and Pelling, J.C. 2008. Enhancement of UVB-induced apoptosis by apigenin in human keratinocytes and organotypic keratinocyte cultures. Cancer Res. 68, 8, 3057-3065.

Aklillu, E., Djordjevic, N., Carrillo, J. A., Makonnen, E., Bertilsson, L., \& IngelmanSundberg, M. (2014). High CYP2A6 enzyme activity as measured by a caffeine test and unique distribution of CYP2A6 variant alleles in Ethiopian population. Omics: a journal of integrative biology.

Augustin, C., Frei, V., Perrier, E., Collombel, C., and Damour, O. 1996. Cellular engineeiring for cosmetology trials: dermal equivalent for determining cutaneous irritation and efficiency. Annual International Conference of The Engineering in Medicine and Biology Society. Amsterdam.

Bedoni, M., Sforza, C., Dolci, C., and Donetti, E. 2007. Proliferation and differentiation biomarkers in normal human breast skin organotypic cultures. $J$. Dermatol. Sci. 46, 2, 139-142.

Botham, P.A., Earl, L.K., Fentem, J.H., Roguet, R., and Van De Sandt, J.J.M. 1998. Alternative methods for skin irritation testing: The current status. ATLA-Altern. Lab. Anim. 26, 195-211.

Bruggisser, R., Von Daeniken, K., Jundt, G., Schaffner, and W., Tulberg-Reinert, H. 2002. Interference of plant extracts, phytoestrogens and antioxidants with the MTT tetrazolium assay. Planta Med. 68, 445-448.

Chen, J.H., and Ho, C.T. 1997. Antioxidant activities of caffeic acid and its related hydroxycinnamic acid compounds. J. Agric. Food Chem. 45, 7, 2374-8.

Chiari, B.G., Martini, P.C., Moraes, J.D.D., Andréo, R., Corrêa, M.A., Cicarelli, R.M.B., and Isaac, V.L.B. 2012. Use of HepG2 cells to assay the safety of cosmetic active substances. Int. J. Res. Cosm. Sci. 2, 2, 8-14.

Djordjevic, N., Ghotbi, R., Jankovic, S., \& Aklillu, E. (2010). Induction of CYP1A2 by heavy coffee consumption is associated with the CYP1A2- 163C $>\mathrm{A}$ polymorphism. European journal of clinical pharmacology, 66(7), 697-703. 
Dossiê de antioxidantes. Os antioxidantes. Available in: $<$ http://www.revistafi.com/materias/83.pdf.> Access on 27th March 2014.

Heise, R., Mey, J., Neis, M.M., Marquardt, Y., Joussen, S., Ott, H., Wiederholt, T., Kurschat, P., Megahed, M., Bickers, D.R., Merk, H.F., and Baron, J.M. 2006. Skin retinoid concentrations are modulated by CYP26AI expression restricted to basal keratinocytes in normal human skin and differentiated 3D skin models. $J$. Invest. Dermatol. 126, 11, 2473-2480.

Hynes, M.J., and O'Coinceanainn, W. 2004. The kinetics and mechanisms of reactions of iron (III) with caffeic acid, chlorogenic acid, sinapic acid, ferulic acid and naringin. J. Inorg. Biochem. 98, 1457-64.

Livny, O., Kaplan, I., Reifen, R., Polak-Charcon, S., Madar, Z., and Schwartz, B. 2003. Oral cancer cells differ from normal oral epithelial cells in tissue like organization and in response to lycopene treatment: an organotypic cell culture study. Nutr. Câncer. 47, 2, 95-209.

Magnani, C., Isaac, V. L. B, Correa, M. A, and Salgado, H. R. N. 2014. Caffeic acid: a review of its potential use in medications and cosmetics. Anal. Methods. DOI: $10.1039 / \mathrm{c} 3 a y 41807 \mathrm{c}$.

Medina, J., Brugerolle De Fraissinette, A., Chibout, S., Kolopp, M., Kammermann, R., Burtin, P., Ebelin, M., and Cordier, A. 2000. Use of human skin equivalent apligraf for in vitro assessment of cumulative skin irritation potential of topical products. Toxicol. Appl. Pharmacol. 164, 38-45.

Meyer, A.S., Donovan, J.L., Pearson, D.A., Waterhouse, A.L., and Frankel, E.N. 1998. Fruit hydroxycinnamic acids inhibit low density lipoprotein oxidation in vitro. J. Agric. Food Chem. 46, 1783-1787.

Paiva-Martins, F., and Gordon, M.H. 2002. Effects of pH and ferric ions on the antioxidant activity of olive polyphenols in oil-in-water emulsions. J. Amer. Oil Chem. Soc. 79, 6, 571-6.

Rabachini, T. 2007. Efeito da rapamicina em culturas organotípicas de queratinócitos que expressam oncoproteínas de papilomavírus humano tipo 16. São Paulo: Universidade de São Paulo, 2007. 148f. Tese (Doutorado em Ciências Biológicas) - Instituto de Química, Universidade de São Paulo, São Paulo.

Soares, S.E. 2002. Ácidos fenólicos como antioxidantes. Rev. Nutr. 15, 1,71-81.

Viravaidya, K., Sin, A., and Shuler, M.L. 2004. Development of a microscale cell culture analog to probe naphthalene toxicity. Biotechnol. Prog. 20, 316-323.

Zhang, Y., Wu, L., Tashiro, S., Onodera, S., and Ikejima, T. 2004. Evadiamine induces tumor cell death through different pathways: apoptosis and necrosis. Acta Pharm. 25, 83-89. 